\title{
Frequency of neurological involvement in patients with/without diarrhea hemolytic uremic syndrome: A Systematic review and meta-analysis
}

\author{
Azita Tavasoli ${ }^{1}$, Shahrbanoo Nakhaiee ${ }^{1}$, Nazanin Zafaranloo $^{1}$, Rozita Hoseini ${ }^{1}$, Hasan Otukesh ${ }^{\mathbb{1}}$, Behnam Sobouti ${ }^{{ }^{*}}$ (D) \\ Received: 20 Oct 2020 \\ Published: 17 Jul 2021
}

\section{Abstract}

Background: Diarrhea-associated-hemolytic-uremic-syndrome (D+HUS) is a common from of HUS. Central-nervous-system (CNS) involvement is one of the most common extrarenal organ involvements in children with D+HUS. This systematic review and meta-analysis aim to recognize the frequency of neurological complications in pts with HUS.

Methods: Databases of PubMed, Embase, and Web of Science were searched systematically to find the papers on neurological involvement in HUS pts. Two researchers independently assessed the papers' quality and extracted data. CMA v. 2.2.064. was used for data analysis. Heterogeneity was evaluated using the I-squared (I2) test, and a fixed/random-effects model was used when appropriate.

Results: In this review, 21 studies including 2,189 participants with a median age between 1.3-40-year-old, entered the metaanalysis. The meta-analysis in D+HUS patients indicated $27.0 \%$ with neurological complications (95\% CI, 22.0\%-32.6\%), $25.5 \%$ of symptoms weren't categorized (95\% CI, 15.9\%-38.3\%), 20.8\% of them developed the seizures (95\% CI, $2.3 \%-74.4 \%)$. In D-HUS pts, $20.8 \%$ of them were presented neurological symptoms (95\% CI, 17.9\%-24.0\%), of which $29.0 \%$ weren't categorized (95\% CI, $19.2 \%$ $41.2 \%), 17.5 \%$ of pts got into coma (95\% CI, 9.6\%-29.7\%), $5.6 \%$ showed hemiparesis $(95 \%$ CI, 2.8\%-10.9\%), $17.2 \%$ experienced lethargy (95\% CI, 5.2\%-44.1\%), 30.5\% developed the seizures (95\% CI, 18.2\%-46.2\%), 7.4\% manifested speech abnormalities (95\% CI, $0.2 \%-7.22 \%), 6.4 \%$ of D-HUS pts presented visual-disturbances $(95 \% \mathrm{CI}, 3.4 \%-11.6 \%)$.

Conclusion: This systematic review and meta-analysis indicated more than one-fourth of both D+HUS and D-HUS patients were presented with neurological symptoms, and the most prevalent symptoms were seizures, which can lead to an epilepsy sequel.

Keywords: HUS, CNS, Diarrhea, Neurological symptoms, Pediatrics, Adults

\author{
Conflicts of Interest: None declared. \\ Funding: None \\ *This work has been published under CC BY-NC-SA 1.0 license.
Copyright $\odot \underline{\text { Iran University of Medical Sciences }}$
}

Cite this article as: Tavasoli A, Nakhaiee Sh, Zafaranloo N, Hoseini R, Otukesh H, Sobouti B. Frequency of neurological involvement in patients with/without diarrhea hemolytic uremic syndrome: A Systematic review and meta-analysis. Med J Islam Repub Iran. 2021 (17 Jul);35:91. https://oi.org/10.47176/mjiri.35.91

\section{Introduction}

Hemolytic-uremic syndrome (HUS) is a group of hemolytic disorders introduced by Gasser et al. (1) in 1995 and considered by low red blood cells and platelets, as well as acute kidney injury (2). HUS's initial symptoms include bloody and/or watery diarrhea, fever, vomiting, and fatigue $(1,2)$. Following initial symptoms, decreases in platelet levels and ki dney failure would occur (2). Although HUS mainly affects the children at pre-school age,

\section{Corresponding author: Dr Behnam Sobouti, sobouti.b@iums.ac.ir}

\footnotetext{
${ }^{1 .}$ Ali-Asghar Children Hospital, Iran University of Medical and Sciences, Tehran, Iran
}

outcomes are more critical in adults with the development of neurological sequels and heart failure (2).

Diarrhea-associated hemolytic uremic syndrome (D HUS) is the most common form of HUS, which includes almost $90 \%$ of HUS patients and leads to acute renal failure (ARF) in children under five years $(3,4)$. The leading cause of $\mathrm{D}^{+} \mathrm{HUS}$ is Shiga-like toxin infection producing by Escherichia coli (E. coli) bacterium (mostly

$\uparrow$ What is "already known" in this topic:

It is about the importance of CNS complications in HUS disease.

\section{$\rightarrow$ What this article adds:}

This article adds to our previous known knowledge that is the Neurologic complications should be monitored in all types of HUS in adults and children. The most common presentation of neurologic complications is a seizure that can lead to epilepsy. 
O157:H7 type) (5). The HUS type that does not associate with diarrhea (D־HUS), mostly cases by Streptococcus pneumoniae infection, and atypical HUS (aHUS) are associated with inherited vs. non-inherited complement regulation disorders (5). One of the long-term complications of HUS is renal problems. In this case, a meta-analysis of Garg et al. indicated $12 \%$ of end-stage renal disease (ESRD) or death in $\mathrm{D}^{+} \mathrm{HUS}$ cases and $25 \%$ long-term renal disorders (6). Although neurological involvements are not as common as renal disorders, central nervous system (CNS) involvement is the primary cause of death in $\mathrm{D}^{+}$HUS patients $(7,8)$.

Hence, due to the lack of comprehensive study on the frequency of neurological complications, this study aims to use meta-analysis to regulate numerical data reported in the literature to quantify the burden of the matter better and integrate what is already known.

\section{Methods}

\section{Study Design \& Search Strategy}

The Preferred Reporting Items for Systematic Reviews and Meta-Analyses (PRISMA) checklist was used for providing different steps of the study. Databases of PubMed, Embase and Web of Science were searched systematically up to June 28, 2020. The search strategy included all MeSH terms and free keywords found for "Hemolytic Uremic Syndrome, "sequel*", and "neurology*" as follows: ("Hemolytic Uremic Syndrome" OR "Hemolytic-Uremic" OR "Gasser's Syndrome" OR "Gassers Syndrome" OR "Gasser Syndrome" OR "Hemolytic-Uremic Syndrome") AND ("associated disease" OR sequelae OR sequels OR "coexistent disease" OR "concomitant disease" OR "associated conditions" OR "coexistent conditions" OR "concomitant conditions" OR complications) AND (Neurological OR Neurology). The search was limited to English studies, but there were no time and location limitations in this regard.

\section{Inclusion and exclusion criteria}

Studies comprised of meta-analysis: comparative/noncomparative studies with retrospective/prospective nature, which reported the neurological complications in HUS patients. In vitro studies, experimental studies, reviews, case reports, and duplicate publications were excluded.

\section{Data extraction \& quality assessment}

Variables such as first author name, year of publication, study region, study design, number of patients, age, neurological complications, mean age, follow-up duration, and mortality. For quality assessment, the modified Newcastle-Ottawa Scale (NOS) was used.

\section{Data analysis}

Comprehensive Meta-Analysis (CMA) v. 2.2.064 software was used for statistical analysis. The I-square $\left(\mathrm{I}^{2}\right)$ test was used for the heterogeneities assessment. The pooling of effect sizes was done with $95 \%$ Confident Interval (CI). According to the study's heterogeneity, a fixed-effects/random-effects model was used as appropriate for heterogeneity more/less than $50 \%$, respectively.

\section{Publication bias}

Begg's and Egger's tests were performed to evaluate publication bias, and the funnel plot has presented. A Pvalue of less than 0.05 was measured as statistically significant.

\section{Results}

\section{Study selection \& characteristics}

The initial database search resulted in 926 papers. After duplicated publication removall and title/abstract screening step, 114 papers were included in the eligibility assessment step. Finally, 22 papers entered into the qualitative synthesis, of which 21 papers entered the meta-analysis.
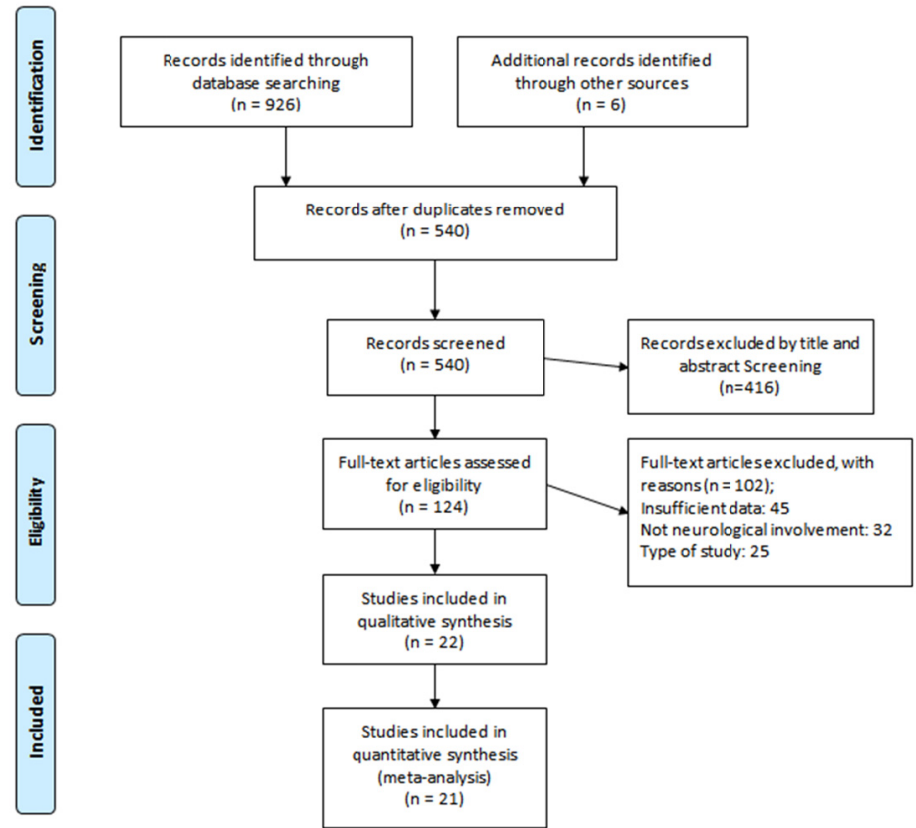

Fig. 1. PRISMA Flow-chart for the study selection process 


\begin{tabular}{|c|c|c|c|c|c|c|c|c|c|c|}
\hline \multirow[t]{2}{*}{ Study } & \multirow[t]{2}{*}{ Country } & \multirow{2}{*}{$\begin{array}{l}\text { Study } \\
\text { design }\end{array}$} & \multirow{2}{*}{$\begin{array}{l}\text { No. of Patients } \\
\text { (male/female) }\end{array}$} & \multirow{2}{*}{$\begin{array}{c}\text { Age, } \\
\text { median } \\
\text { (IQR) }\end{array}$} & \multicolumn{2}{|c|}{ Neurological Signs and symptoms } & \multirow[t]{2}{*}{ Neurological squeals } & \multirow[t]{2}{*}{$\overline{\text { EEG }}$} & \multirow{2}{*}{$\begin{array}{l}\text { Duration } \\
\text { of study }\end{array}$} & \multirow[t]{2}{*}{ Death } \\
\hline & & & & & Diarrhea ${ }^{-}$HUS Patients & Diarrhea $^{+}$HUS Patients & & & & \\
\hline $\begin{array}{l}\text { Elzouki et al. } \\
(1995)(9)\end{array}$ & $\begin{array}{c}\text { Saudi } \\
\text { Arabia }\end{array}$ & RCS & $\begin{array}{c}28 \\
(14 / 14)\end{array}$ & 2.2 & - & $\begin{array}{l}\text { Neurologic complica- } \\
\text { tions: } 11\end{array}$ & - & - & 15 months & - \\
\hline $\begin{array}{l}\text { Qamar et al. } \\
\text { (1996) (10) }\end{array}$ & Canada & $\mathrm{RCS}$ & $\begin{array}{c}7 \\
(3 / 4)\end{array}$ & 2.4 & $\begin{array}{l}\text { Seizure: } 7 \\
\text { Irritability: } 2 \\
\text { Delirium: } 1\end{array}$ & & - & $\begin{array}{c}\text { Normal: } 2 \\
\text { Abnormal: } 2 \\
\text { No-reported: } 3\end{array}$ & 6 years & 1 \\
\hline $\begin{array}{l}\text { Cimolai et al. } \\
\text { (1998) (11) }\end{array}$ & Canada & RCS & 51 & - & - & $\begin{array}{c}\text { Neurological complica- } \\
\text { tions: } 11 \\
\text { Encephalopathy: } 6 \\
\text { Seizure: } 7\end{array}$ & - & - & 11 years & 2 \\
\hline $\begin{array}{l}\text { Schlieper et al. } \\
\text { (1999) (12) }\end{array}$ & Canada & RCS & 205 & 8.6 & $\begin{array}{l}\text { Lethargy: } 58 \\
\text { Seizures: } 9 \\
\text { Coma: } 1\end{array}$ & - & - & - & 3 year & - \\
\hline $\begin{array}{l}\text { Eriksson et al. } \\
(2001)(13)\end{array}$ & UK & RCS & $\begin{array}{c}22 \\
(11 / 11)\end{array}$ & 3.3 & $\begin{array}{l}\text { Coma: } 9 \\
\text { Seizures: } 14\end{array}$ & - & $\begin{array}{c}\text { Epilepsy: } 2 \\
\text { Dysphasia: } 1 \\
\text { Visual problem: } 2 \\
\text { Homonymous hemianopia: } 1 \\
\text { Cognitive deficit: } 1\end{array}$ & $\begin{array}{l}\text { Early EEG } \\
\text { Slow: } 17 \\
\text { Periodic: } 5\end{array}$ & 7 years & 5 \\
\hline $\begin{array}{l}\text { Yamamoto et al. } \\
\text { (2009) (14) }\end{array}$ & Japan & RCS & $\begin{array}{c}71 \\
(27 / 44)\end{array}$ & - & - & $\begin{array}{c}\text { Lethargy: } 7 \\
\text { Headache: } 1\end{array}$ & - & - & - & - \\
\hline $\begin{array}{l}\text { Nathanson et al. } \\
\text { (2010) (15) }\end{array}$ & France & RCS & 52 & - & - & $\begin{array}{c}\text { Alteration in conscious- } \\
\text { ness: } 44 \\
\text { Seizures: } 37 \\
\text { Pyramidal syndrome: } 27 \\
\text { Pyramidal syndrome } \\
\text { with hypertonia: } 22 \\
\text { Coma and seizures in } \\
\text { addition to pyramidal } \\
\text { and extrapyramidal } \\
\text { syndromes: } 12\end{array}$ & $\begin{array}{c}\text { Hemiparesia: } 3 \\
\text { Dystonia: } 1 \\
\text { Ataxia: } 1 \\
\text { Dysphasia: } 1 \\
\text { Epilepsy: } 2 \\
\text { Tetraparesia: } 1 \\
\text { Blindness: } 1 \\
\text { Pyramidal: } 1 \\
\text { Claude Bernard } \\
\text { Horner: } 1 \\
\text { Visual defect: } 1 \\
\text { Developmental delay: } 1 \\
\text { Severe disability: } 5\end{array}$ & - & 33 years & 9 \\
\hline
\end{tabular}




\begin{tabular}{|c|c|c|c|c|c|c|c|c|c|c|}
\hline \multirow[t]{2}{*}{ Study } & \multirow[t]{2}{*}{ Country } & \multirow{2}{*}{$\begin{array}{c}\text { Study } \\
\text { design }\end{array}$} & \multirow{2}{*}{$\begin{array}{c}\text { No. of } \\
\text { Patients } \\
\text { (male/female) }\end{array}$} & \multirow{2}{*}{$\begin{array}{l}\text { Age, median } \\
\text { (IQR) }\end{array}$} & \multicolumn{2}{|c|}{ Neurological Signs and symptoms } & \multirow{2}{*}{$\begin{array}{c}\text { Neurological } \\
\text { squeals }\end{array}$} & \multirow[t]{2}{*}{$\overline{\text { EEG }}$} & \multirow{2}{*}{$\begin{array}{l}\text { Duration } \\
\text { of study }\end{array}$} & \multirow[t]{2}{*}{ Death } \\
\hline & & & & & Diarrhea-HUS Patients & $\begin{array}{c}\text { Diarrhea }^{+} \text {HUS } \\
\text { Patients }\end{array}$ & & & & \\
\hline $\begin{array}{l}\text { de Souza et al. } \\
\text { (2011) (16) }\end{array}$ & Brazil & $\begin{array}{l}\text { Prospec- } \\
\text { tive co- } \\
\text { hort }\end{array}$ & $\begin{array}{c}13 \\
(5 / 8)\end{array}$ & 3.2 & Neurological symptoms: 4 & - & - & - & 5 years & - \\
\hline $\begin{array}{l}\text { Loos et al. (2012) } \\
\text { (17) }\end{array}$ & Germany & RCS & $\begin{array}{c}90 \\
(41 / 49)\end{array}$ & 11.5 & $\begin{array}{cc}\text { Neurological Symptoms: } 23 \\
\text { - } & \text { Seizures: } 16 / 23 \\
\text { - } & \text { Impaired con- } \\
& \text { sciousness } \\
\text { - } & \text { Including coma: } \\
& 17 / 23 \\
\text { - } & \text { Visual disturb- } \\
& \text { ances: } 7 / 23\end{array}$ & - & - & - & 3 months & 1 \\
\hline $\begin{array}{l}\text { Rosales et al. } \\
\text { (2012) (18) }\end{array}$ & Germany & RCS & 690 & 2.9 & $\begin{array}{c}\text { Seizures, coma, stroke, } \\
\text { and severely retarded motor } \\
\text { development }\end{array}$ & - & - & - & 6 years & 7 \\
\hline $\begin{array}{l}\text { Ekinci et al. } \\
\text { (2013) (19) }\end{array}$ & Turkey & RCS & $\begin{array}{c}70 \\
(33 / 37)\end{array}$ & 7.07 & CNS involvement: 15 & - & - & - & - & 3 \\
\hline $\begin{array}{l}\text { Braune et al. } \\
\text { (2013) (20) }\end{array}$ & Germany & RCS & $\begin{array}{c}106 \\
(24 / 82)\end{array}$ & $\begin{array}{c}40 \\
(18-83)\end{array}$ & $\begin{array}{c}\text { Severe neurological symptoms } \\
\text { and signs: } 70 \\
\text { Cognitive dysfunction: } 39 \\
\text { Aphasia: } 31 \\
\text { Epileptic seizures: } 31 \\
\text { Myoclonus: } 25\end{array}$ & - & - & - & 4 months & 5 \\
\hline $\begin{array}{l}\text { Bauer et al. (2014) } \\
\text { (21) }\end{array}$ & Germany & RCS & $\begin{array}{c}50 \\
(23 / 27)\end{array}$ & 11.9 & $\begin{array}{cc}\text { Neurological involvement: } 14 \\
\text { - } & \text { Seizure: } 11 / 14 \\
& \text { Impaired conscious- } \\
& \text { ness: } 11 / 14 \\
\text { - } & \text { Visual disturbances: } \\
& 4 / 14 \\
\text { - } & \text { Myocloni: } 3 / 14 \\
\text { - } & \text { Hemiparesis: } 2 / 14\end{array}$ & - & Hemiparesis: 1 & $\begin{array}{c}\text { Abnormal: } 25 / 39 \\
\text { Slowing of } \\
\text { background activity: } 21 / 39 \\
\text { Focal slowing: } 5 / 39 \\
\text { Epileptic discharges: } 5 / 39\end{array}$ & 1 year & 1 \\
\hline
\end{tabular}

$4 \quad$ http://mjiri.iums.ac.ir

Med J Islam Repub Iran. 2021 (17 Jul); 35:91. 


\begin{tabular}{|c|c|c|c|c|c|c|c|c|c|c|}
\hline \multirow[t]{2}{*}{ Study } & \multirow[t]{2}{*}{ Country } & \multirow[t]{2}{*}{ Study design } & \multirow{2}{*}{$\begin{array}{c}\text { No. of } \\
\text { Patients } \\
\text { (male/female) }\end{array}$} & \multirow{2}{*}{$\begin{array}{l}\text { Age, median } \\
\text { (IQR) }\end{array}$} & \multicolumn{2}{|c|}{ Neurological Signs and symptoms } & \multirow{2}{*}{$\begin{array}{l}\text { Neurologi- } \\
\text { cal squeals }\end{array}$} & \multirow[t]{2}{*}{ EEG } & \multirow{2}{*}{$\begin{array}{l}\text { Duration } \\
\text { of study }\end{array}$} & \multirow[t]{2}{*}{ Death } \\
\hline & & & & & Diarrhea HUS Patients & $\begin{array}{l}\text { Diarrhea }{ }^{+} \text {HUS } \\
\text { Patients }\end{array}$ & & & & \\
\hline $\begin{array}{l}\text { Buder et al. } \\
\text { (2015) (22) }\end{array}$ & Germany & $\begin{array}{c}\text { Retrospective } \\
\text { cohort }\end{array}$ & $\begin{array}{c}16^{*} \\
(6 / 10)\end{array}$ & $\begin{array}{c}1.3 \\
(0.3-14.4)\end{array}$ & $\begin{array}{c}\text { Seizures: } 12 / 16 \\
\text { Isolated seizures: } 5 / 16 \\
\text { Altered consciousness: } 7 / 16 \\
\text { Isolated altered consciousness: } \\
2 / 16 \\
\text { Ataxia: } 4 / 16 \\
\text { Muscle tone abnormality: } 2 / 16 \\
\text { Hemiplegic symptoms: } 2 / 16 \\
\text { Dysarthria: } 1 / 16 \\
\text { Visual disorders: } 1 / 16 \\
\text { Movement disorders: } 2 / 16 \\
\text { Vestibular symptoms: } 1 / 16 \\
>1 \text { neurological symptom: } 8 / 16 \\
\text { Number of neurological symp- } \\
\text { toms: } \\
\text { 1: } 8 / 16 \\
2: 5 / 16 \\
3: 0 / 16 \\
4: 1 / 16 \\
5: 2 / 16\end{array}$ & - & - & - & 1 year & - \\
\hline $\begin{array}{l}\text { Jenssen et al. } \\
\text { (2016) (23) }\end{array}$ & Norway & RCS & $\begin{array}{c}47 \\
(16 / 31)\end{array}$ & 2 & Neurological complications: 2 & $\begin{array}{l}\text { Neurological com- } \\
\text { plications: } 9\end{array}$ & - & - & 10 years & 2 \\
\hline $\begin{array}{l}\text { Durkan et al. } \\
\text { (2016) (24) }\end{array}$ & Australia & $\begin{array}{l}\text { Prospective } \\
\text { cohort }\end{array}$ & $\begin{array}{c}122 \\
(65 / 57)\end{array}$ & 2.9 & Neurological involvement: 23 & - & - & - & 8 years & - \\
\hline $\begin{array}{l}\text { Şahin et al. } \\
\text { (2017) (25) }\end{array}$ & Turkey & RCS & 64 & - & $\begin{array}{c}\text { Neurological involvement: } 24 \\
\text { Seizure: } 15 \\
\text { Headache: } 6 \\
\text { Motor paresis with pyramidal tract } \\
\text { signs: } 6 \\
\text { Alteration of consciousness: } 5 \\
\text { Sensory symptoms: } 3\end{array}$ & - & - & $\begin{array}{l}\text { Abnormal: } 7 / 13 \\
\text { Slow-wave: } 4 / 13 \\
\text { Epileptiform ab- } \\
\text { normalities: } 2 / 13\end{array}$ & 10 years & 6 \\
\hline $\begin{array}{l}\text { Loos et al. (2017) } \\
\text { (26) }\end{array}$ & Germany & RCS & 72 & 11.55 & Neurological symptoms: 19 & - & - & - & 1 year & 1 \\
\hline
\end{tabular}




\begin{tabular}{|c|c|c|c|c|c|c|c|c|c|c|}
\hline \multirow[t]{2}{*}{ Study } & \multirow[t]{2}{*}{ Country } & \multirow{2}{*}{$\begin{array}{l}\text { Study } \\
\text { design }\end{array}$} & \multirow{2}{*}{$\begin{array}{c}\text { No. of } \\
\text { Patients } \\
\text { (male/female) }\end{array}$} & \multirow{2}{*}{$\begin{array}{l}\text { Age, median } \\
\text { (IQR) }\end{array}$} & \multicolumn{2}{|c|}{ Neurological Signs and symptoms } & \multirow{2}{*}{$\begin{array}{l}\text { Neurologi- } \\
\text { cal squeals }\end{array}$} & \multirow[t]{2}{*}{ EEG } & \multirow{2}{*}{$\begin{array}{l}\text { Duration } \\
\text { of study }\end{array}$} & \multirow[t]{2}{*}{ Death } \\
\hline & & & & & Diarrhea ${ }^{-}$HUS Patients & $\begin{array}{c}\text { Diarrhea }{ }^{+} \text {HUS } \\
\text { Patients }\end{array}$ & & & & \\
\hline $\begin{array}{l}\text { Karnisova et al. } \\
(2018)(27)\end{array}$ & $\begin{array}{c}\text { Czech } \\
\text { Republic }\end{array}$ & $\mathrm{RCS}$ & $\begin{array}{c}33 \\
(18 / 15)\end{array}$ & 2.4 & - & $\begin{array}{c}\text { Impaired con- } \\
\text { sciousness: } 4 \\
\text { Seizures: } 1 \\
\text { Paleocerebellar } \\
\text { syndrome: } 2 \\
\text { Quadriparesis: } 1 \\
\text { Cranial nerve palsy: } \\
2 \\
\text { Hallucinations: } 1\end{array}$ & - & - & 16 years & - \\
\hline $\begin{array}{l}\text { Clech et al. } \\
\text { (2019) (28) }\end{array}$ & France & RCS & 235 & - & Neurologic involvement: 30 & - & - & - & 18 years & - \\
\hline $\begin{array}{l}\text { Tavasoli et al. } \\
\text { (2019) (29) }\end{array}$ & Iran & RCS & 58 & 3.4 & CNS involvement: 31 & - & - & - & 14 years & 8 \\
\hline $\begin{array}{l}\text { Ylinen et al. } \\
\text { (2020) (30) }\end{array}$ & Finland & RCS & 87 & - & $\begin{array}{c}\text { Seizures: } 24 \\
\text { Impaired consciousness: } 15 \\
\text { Hemiparesis: } 4 \\
\text { Minor CNS symptoms: } 12 \\
\text { Lethargy: } 8 \\
\text { Irritability: } 2 \\
\text { Vision abnormality: } 1 \\
\text { Speech abnormality: } 1 \\
\text { Fluctuating hemiparesis: } 1\end{array}$ & - & - & - & 15 years & - \\
\hline
\end{tabular}

* patients with CNS involvement during acute episode of HUS 
PRISMA flow diagram for the study selection process is presented in Figure 1. The sample size of studies included in the systematic review ranged from 7 to 690 , including 2,189 participants with a median age between 1.3 to 40 years old. Characteristics of studies included in the systematic review presented in Table 1.

\section{Quality assessment}

Results of the quality assessment for studies entered into meta-analysis based on a modified version of the NOS tool for cross-sectional studies were fair.

\section{Publication bias}

Begg's and Egger's tests in effect size meta-analysis showed no significant publication bias for both $\mathrm{D}^{+} \mathrm{HUS}$ patients $\left(\mathrm{P}_{\mathrm{B}}=0.60 ; \mathrm{P}_{\mathrm{E}}=0.54\right)$ and $\mathrm{D}^{-} \mathrm{HUS}$ patients
$\left(\mathrm{P}_{\mathrm{B}}=0.78 ; \mathrm{P}_{\mathrm{E}}=0.77\right)$. The funnel plot for publication bias of studies presented in Figure 2.

\section{Meta-analysis findings}

The meta-analysis of event rates in $\mathrm{D}^{+} \mathrm{HUS}$ patients indicated that $27.0 \%$ of such patients manifested neurological complications (95\% CI, 22.0\%-32.6\%), of which $25.5 \%$ of symptoms were not categorized $(95 \% \mathrm{CI}$, $15.9 \%-38.3 \%$ ), and $20.8 \%$ of such patients developed the seizures $(95 \%$ CI, 2.3\%-74.4\%). Other neurological symptoms that only reported in single studies were alteration in conciseness $(84.6 \%)$, coma $(12.1 \%)$, cranial nerve palsy (6.1\%), encephalopathy (11.8\%), hallucinations $(3.0 \%)$, headache $(1.4 \%)$, lethargy $(9.9 \%)$, paleocerebellar syndrome $(6.1 \%)$, pyramidal syndrome $(51.9 \%)$, and quadriparesis (3.0\%) (Fig. 3).
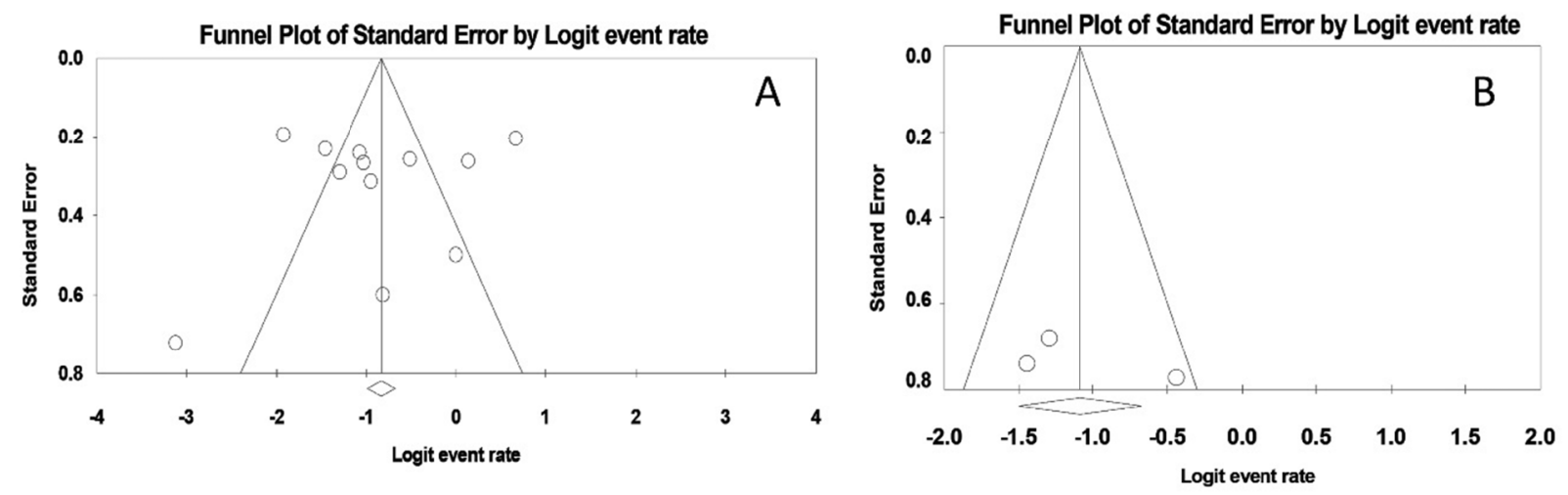

Fig. 2. Funnel plot for publication bias; (A): D'HUS patients, (B): D ${ }^{+} H U S$ patients

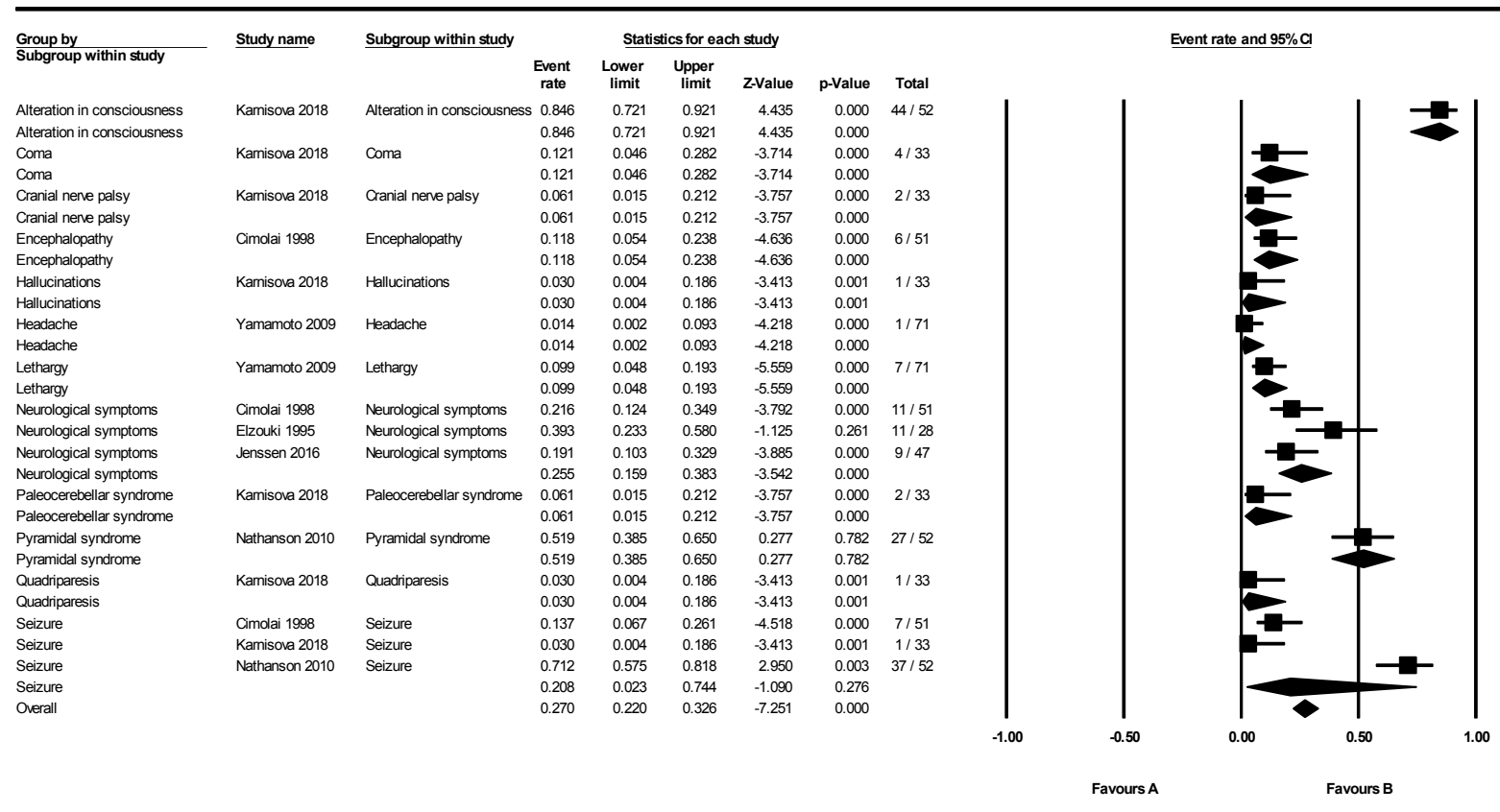


Among D־HUS patients, $20.8 \%$ of them were presented neurological symptoms (95\% CI, 17.9\%-24.0\%), of which $29.0 \%$ of patients' symptoms were not categorized $(95 \%$ CI, $19.2 \%-41.2 \%), 17.5 \%$ of patients got into coma $(95 \%$ CI, 9.6\%-29.7\%), $5.6 \%$ showed hemiparesis (95\% CI, $2.8 \%-10.9 \%), \quad 17.2 \%$ experienced lethargy (95\% CI, $5.2 \%-44.1 \%), 30.5 \%$ developed the seizures (95\% CI, $18.2 \%-46.2 \%), 7.4 \%$ manifested speech abnormalities (95\% CI, $0.2 \%-7.22 \%$ ), and $6.4 \%$ of DHUS patients presented visual disturbances (95\% CI, 3.4\%-11.6\%). Other neurological symptoms that only reported in single studies were aphasia $(29.2 \%)$, ataxia $(25.0 \%)$, cognitive dysfunction $(36.8 \%)$, delirium $(14.3 \%)$, headache $(9.4 \%)$, and irritability (28.6\%), and motor paresis (9.4\%) (Fig. 4).

In total, $24.4 \%$ of HUS patients with/without diarrhea were presented neurological symptoms (95\% CI, 21.6\%27.5\%) (Fig. 5).

\section{Discussion}

The most studied subject on HUS patients has focused on renal problems $(6,31)$. There are a few well-organized studies with long-term follow-up, which considered the neurodevelopmental complications among such patients. Also, to our knowledge, there is no systematic review and meta-analysis on the subject. Hence, we have gathered all available data on the issue, which only resulted in descriptive outcomes due to the limited information.

We found that more than one-fourth of $\mathrm{D}^{+}$HUS patients were presented neurological symptoms, and the most prevalent symptoms were seizures, which led to epilepsy sequel in some cases that only reported in two studies (13, 15). Other neurological symptoms that were reported include alteration in conciseness, coma, cranial nerve palsy, encephalopathy, hallucinations, headache, lethargy, paleocerebellar syndrome, pyramidal syndrome, and quadriparesis.

The hemolytic uremic syndrome is a multi-organ disease in which CNS involvement occurs in $20-50 \%$ of patients during the acute phase $(32,33)$. This comprehensive range of incidence may be due to the difficulty of diagnosis in the cases of minor CNS manifestations among these children. Regardless of renal involvement high frequency, CNS involvement is the main reason for mortality in Shiga like toxin-producing Escherichia coli (STEC) HUS patients. This fact indicates the microvascular damage in cerebral areas (7).

In in vitro studies, although HUS thrombotic microangiopathic (TMA) was observed in renal vessels, it was not

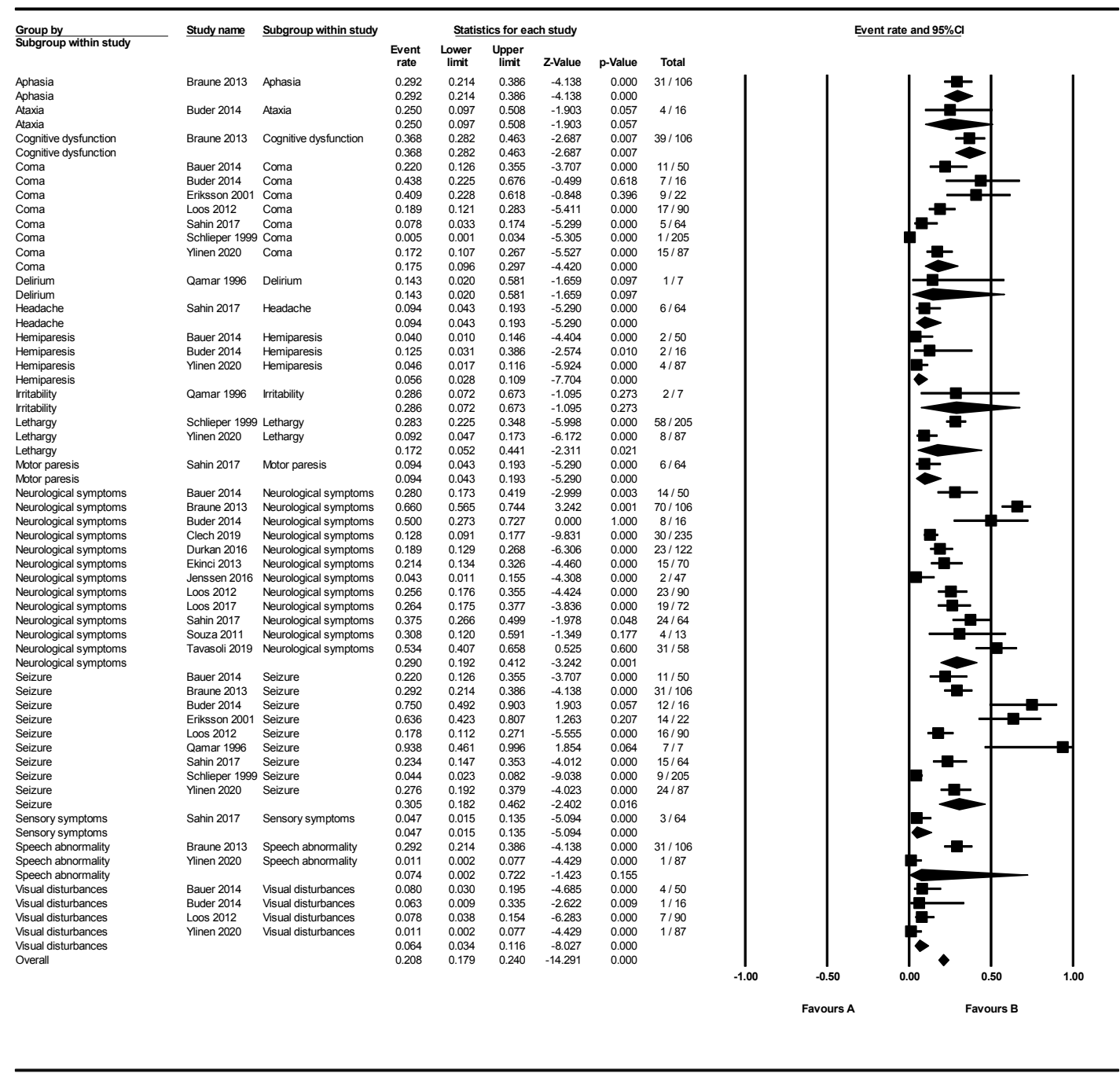

Fig. 4. Frequency of neurological symptoms in D־HUS patients 


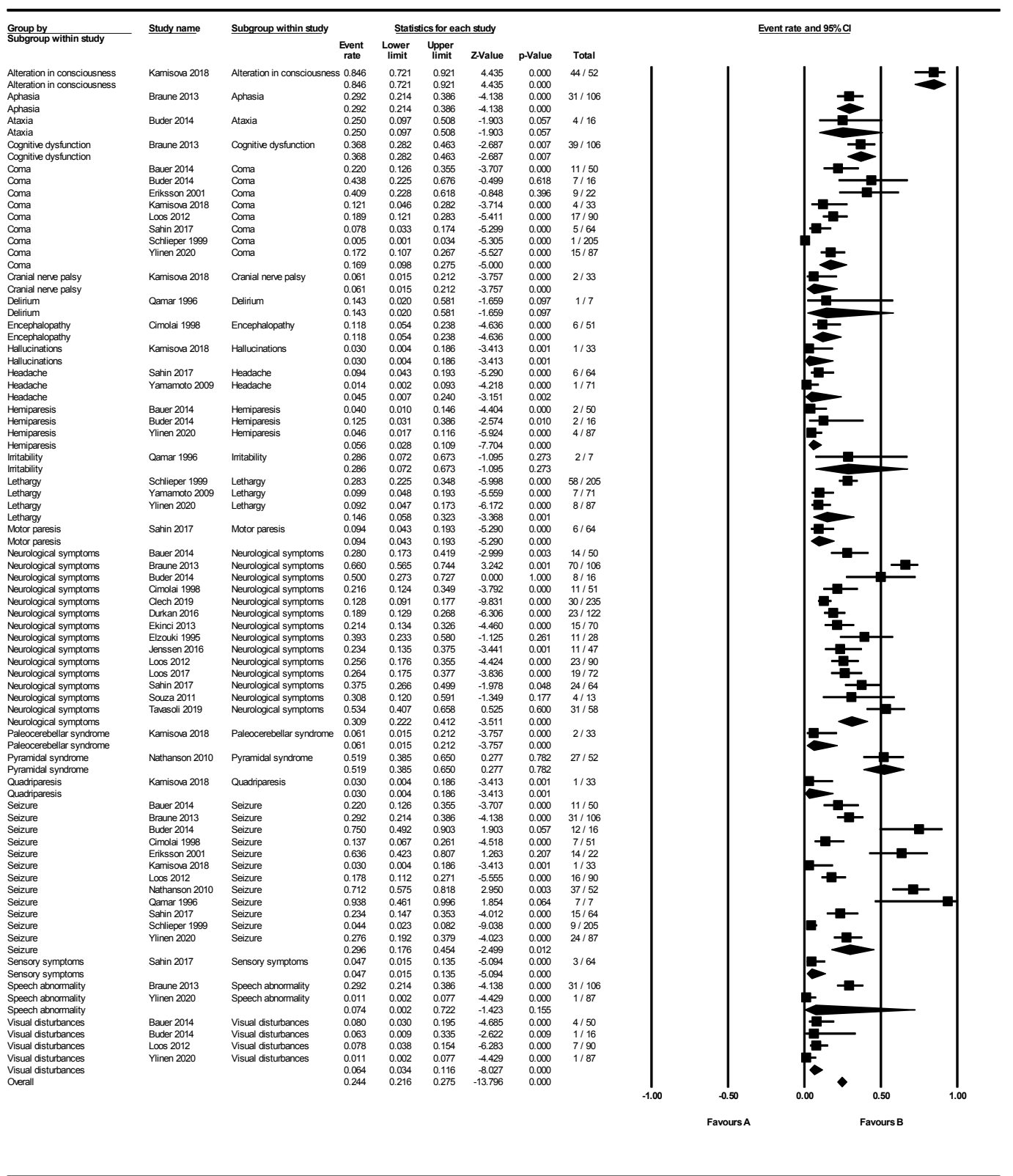

Fig. 5. Frequency of neurological symptoms in HUS patients with/without diarrhea

found in the brain's endothelium $(34,35)$. However, cerebral ischemia due to Shiga toxin was observed in rabbit models; also, arteriolar necrosis of the brain and endothelial cell damage was found in piglet models $(36,37)$. Hence, it can be concluded that various types of endothelium respond to Shiga toxin individually. In this regard, the sensitivity of human intestinal microvascular endothelial cells (HIMEC) to Shiga toxins is much more in comparison to human saphenous vein endothelial cells (HSVEC) (38).

Clinically and experimentally, neurological involvement is the deadliest complication of STEC-HUS. Common manifestations of CNS involvement include altered consciousness, irritability, seizure, coma, hemiparesis, ataxia, apnoea, blindness, varying degrees of encephalopathy, stroke, de-cerebration, and dystonic posture $(5,7)$. Causes of neurological involvement are multifactorial and may be due to generalized insult from metabolic disorders such as hyponatremia, hypocalcemia, and uremia, or due to hypertension. The direct effects of Shiga toxin on the brain's neuronal and endothelial cells may lead to hemorrhage or infarction. Some authors consider microangiopathy as the main cause of CNS involvement in $\mathrm{D}^{+} \operatorname{HUS}(39,40)$. It has also been reported that antecedent enteritis associated with bloody diarrhea and gastrointestinal manifestations might be related to the severity of neurological involvement (7).

In the case of treatment for such patients, there is a lack of evidence-based guidelines. The study of Nathanson et al. (15) indicated promising effects of plasma exchange in HUS patients with critical CNS involvement. Also, the study of Dundas et al. on "Effectiveness of therapeutic plasma exchange in the 1996 Lanarkshire Escherichia coli 
O157:H7 outbreak" in Scotland demonstrated survival effects for plasmapheresis. In this study, although platelet counts recovered to the normal values during one week in $25 \%$ of patients, other patients showed no improvement with the approach. It has also been reported that plasma exchange deteriorated the renal function and increased the neurological complications as well as the dialysis need (8). Hence, plasmapheresis is not generally accepted as a practical approach to treating HUS patients with CNS involvement (41).

In the 2011 O104:H4 outbreak, monoclonal antibody eculizumab was used as a new approach to treating HUS patients with critical neurological involvement. This humanized anti-C5 monoclonal antibody inhibits the complement system and stops developing the terminal complement complex and is approved to be considered for the treatment of paroxysmal nocturnal hemoglobinuria (42). However, various data on the efficacy of the eculizumab demonstrates a wide range of treatment effects in different regions $(17,43)$.

According to the current systematic review and metaanalysis findings, due to the lack of well-organized guidelines and long-term studies on the HUS patients' neurological complications, diagnosis approaches, and treatment applications, further large long-term clinical trials should be taken into account to achieve more reliable findings.

It is worth mentioning that the current study includes several limitations: a) due to lack of long-term studies and analytical data, considering long-term sequels were not probable; b) small sample size of studies would lead to type II statistical errors.

\section{Conclusion}

This systematic review and meta-analysis indicated more than one-fourth of both $\mathrm{D}^{+}$HUS and D'HUS patients were presented with neurological symptoms. The most frequent symptoms were seizure development, which can potentially lead to epilepsy sequel. For overcoming the limitations, robustly long-term controlled randomized studies are recommended.

\section{Acknowledgement}

Special thanks to all the authors and the research center in IRAN University of Medical Sciences

\section{Conflict of Interests}

The authors declare that they have no competing interests.

\section{References}

1. Gasser C, Gautier E, Steck A, Siebenmann RE, Oechslin R. [Hemolytic-uremic syndrome: bilateral necrosis of the renal cortex in acute acquired hemolytic anemia]. Schweizerische Medizinische Wochenschrift. 1955;85(38-39):905-9.

2. Cody EM, Dixon BP. Hemolytic Uremic Syndrome. Pediatr Clin North Am. 2019;66(1):235-46.

3. Lynn RM, O'Brien SJ, Taylor CM, Adak GK, Chart H, Cheasty $\mathrm{T}$, et al. Childhood hemolytic uremic syndrome, United Kingdom and Ireland. Emerging Infect Dis. 2005;11(4):590-6.

4. Nathanson S, Kwon $T$, Elmaleh M, Charbit M, Launay EA,
Harambat $J$, et al. Acute neurollogical involvement in diarrheaassociated hemolytic uremic syndrome. Clin J Am Soc Nephrol. 2010;5(7):1218-28.

5. Tarr PI, Gordon CA, Chandller WL. Shiga-toxin-producing Escherichia coli and haemolytic uraemic syndrome. Lancet. 2005;365(9464):1073-86

6. Garg AX, Suri RS, Barrowman N, Rehman F, Matsell D, Rosas-Arellano MP, et al. Long-term renal prognosis of diarrhea-associated hemolytic uremic syndrome: a systematic review, meta-analysis, and meta-regression. Jama. 2003;290(10): 1360-70.

7. Siegler RL. The hemolytic uremic syndrome. Pediatr Clin North Am. 1995;42(6):1505-29.

8. Trachtman H, Austin C, Lewinski M, Stahl RAK. Renal and neurological involvement in typical Shiga toxin-associated HUS. Nature Rev Nephrol. 2012;8(11):658-69.

9. Elzouki AY, Mirza K, Mahmood A, Al-Sowailem AM. Hemolytic uremic syndrome - clinical aspects and outcome of an outbreak: Report of 28 cases. Ann Saudi Med. 1995;15(2):113-6.

10. Qamar IU, Ohali M, MacGregor DL, Wasson C, Krekewich $\mathrm{K}$, Marcovitch S, et al. Long-term neurological sequelae of hemolytic-uremic syndrome: A preliminary report. Pediatr Nephrol. 1996;10(4):504-6.

11. Cimolai N, Carter JE. Bacterial genotype and neurological complications of Escherichia coli O157: H7 associated haemolytic uraemic syndrome. Acta Paediatr. 1998;87(5):5934.

12. Schlieper A, Orrbine E, Wells GA, Clulow M, McLaine PN, Rowe PC, et al. Neuropsychollogical sequelae of haemolytic uraemic syndrome. Arch Dis Child. 1999;80(3):214-20.

13. Eriksson KJ, Boyd SG, Tasker RC. Acute neurology and neurophysiology of haemolytic-uraemic syndrome. Arch Dis Child. 2001;84(5):434-5.

14. Yamamoto T, Satomura K, Okada S, Ozono K. Risk factors for neurological complications in complete hemolytic uremic syndrome caused by Escherichia coli O157. Pediatr Int. 2009;51(2):216-9.

15. Nathanson S, Kwon T, Elmaleh $M$, Charbit M, Launay EA, Harambat $J$, et al. Acute Neurological Involvement in Diarrhea-Associated Hemolytic Uremic Syndrome. Clin J Am Soc Nephrol. 2010;5(7):1218-28.

16. de Souza RL, Abreu Carvalhaes JT, Sanae Nishimura L, de Andrade MC, Cabilio Guth BE. Hemolytic uremic syndrome in pediatric intensive care units in são paulo, Brazil. Open Microbiol J. 2011;5:76-82.

17. Loos S, Ahlenstiel T, Kranz B, Staude H, Pape L, Härtel C, et al. An outbreak of shiga toxin-producing escherichia coli O104:H4 hemolytic uremic syndrome in Germany: Presentation and short-term outcome in children. Clin Infect Dis. 2012;55(6):753-9.

18. Rosales A, Hofer J, Zimmerhackl LB, Jungraithmayr TC, Riedl M, Giner T, et al. Need for Long-term Follow-up in Enterohemorrhagic Escherichia coli-Associated Hemolytic Uremic Syndrome Due to Late-Emerging Sequelae. Clin Infect Dis. 2012;54(10):1413-21.

19. Ekinci Z, Candan C, Alpay H, Canpolat N, Akyuz SG, Gunduz $Z$, et al. Hemolytic uremic syndrome outbreak in Turkey in 2011. Turk J Pediatr. 2013;55(3):246-52.

20. Braune SA, Wichmann D, von Heinz MC, Nierhaus A, Becker H, Meyer TN, et al. Clinical Features of Critically Ill Patients With Shiga Toxin-Induced Hemolytic Uremic Syndrome. Crit Care Med. 2013;41(7):1702-10.

21. Bauer A, Loos S, Wehrmann C, Horstmann D, Donnerstag F, Lemke J, et al. Neurological involvement in children with E. coli O104:H4-induced hemolytic uremic syndrome. Pediatr Nephrol. 2014;29(9):1607-15.

22. Buder K, Latal B, Nef S, Neuhaus TJ, Laube GF, Spartà G. Neurodevelopmental long-term outcome in children after hemolytic uremic syndrome. Pediatr Nephrol (Berlin, Germany). 2015;30(3):503-13.

23. Jenssen GR, Vold L, Hovlanı E, Bangstad HJ, Nygård K, Bjerre A. Clinical features, therapeutic interventions and longterm aspects of hemolytic-uremic syndrome in Norwegian children: A nationwide retrospective study from 1999-2008. 
BMC Infect Dis. 2016;16(1).

24. Durkan AM, Kim S, Elliott E. The long-term follow-up of children presenting with atypical hemolytic uremic syndrome in Australia between 1994 and 2001. Nephrology. 2016;20:62.

25. Şahin S, Özdoğan EB, Kaya G, Özgün N, Cansu A, Kalyoncu $\mathrm{M}$, et al. Neurological Involvement in Pediatric Hemolytic Uremic Syndrome: A Symptom-Oriented Analysis. Neuropediatrics. 2017;48(5):363-70.

26. Loos S, Aulbert W, Hoppe B, Ahlenstiel-Grunow T, Kranz B, Wahl $\mathrm{C}$, et al. Intermediate Follow-up of Pediatric Patients With Hemolytic Uremic Syndrome During the 2011 Outbreak Caused by E. coli O104:H4. Clin Infect Dis. 2017;64(12):163743.

27. Karnisova L, Hradsky O, Blahova K, Fencl F, Dolezel Z, Zaoral $\mathrm{T}$, et al. Complement activation is associated with more severe course of diarrhea-associated hemolytic uremic syndrome, a preliminary study. Eur J Pediatr. 2018;177(12):1837-44.

28. Le Clech A, Simon-Tillaux N, Provot F, Delmas Y, VieiraMartins P, Limou S, et al. Atypical and secondary hemolytic uremic syndromes have a distinct presentation and no common genetic risk factors. Kidney Int. 2019;95(6):1443-52.

29. Tavasoli A, Zafaranloo N, Hoseini R, Otukesh H, Hooman N, Panahi P. Chronic neurological complications in hemolytic uremic syndrome in children. Iran $\mathrm{J}$ Kidney Dis. 2019;13(1):32-5.

30. Ylinen E, Salmenlinna S, Halkilahti J, Jahnukainen T, Korhonen L, Virkkala $\mathrm{T}$, et al. Hemolytic uremic syndrome caused by Shiga toxin-producing Escherichia coli in children: incidence, risk factors, and clinical outcome. Pediatr Nephrol (Berlin, Germany). 2020.

31. Monet-Didailler C, Godron-Dubrasquet A, Madden I, Delmas Y, Llanas B, Harambat J. Long-term outcome of diarrheaassociated hemolytic uremic syndrome is poorly related to markers of kidney injury at 1-year follow-up in a populationbased cohort. Pediatr Nephrol (Berlin, Germany). 2019;34(4):657-62.

32. Bale JF, Brasher C, Siegler RL. CNS manifestations of the hemolytic-uremic syndrome: relationship to metabolic alterations and prognosis. Am J Dis Child. 1980;134(9):86972 .

33. Cimolai N, Morrison BJ, Carter JE. Risk factors for the central nervous system manifestations of gastroenteritisassociated hemolytic-uremic syndrome. J Pediatrics. 1992;90(4):616-21.

34. Magnus $\mathrm{T}$, Röther J, Simova O, Meier-Cillien M, Repenthin $\mathrm{J}$, Möller F, et al. The neurological syndrome in adults during the 2011 northern German E. coli serotype O104:H4 outbreak. Brain. 2012;135(Pt 6):1850-9.

35. Ohlmann D, Hamann GF, Hassler M, Schimrigk K. [Involvement of the central nervous system in hemolytic uremic syndrome/thrombotic thrombocytopenic purpura]. Der Nervenarzt. 1996;67(10):880-2.

36. Fujii J, Kinoshita Y, Kita T, Higure A, Takeda T, Tanaka N, et al. Magnetic resonance imaging and histopathological study of brain lesions in rabbits given intravenous verotoxin 2. Infect Immun. 1996;64(12):5053-60.

37. Tzipori S, Chow CW, Powell HR. Cerebral infection with Escherichia coli $\mathrm{O} 157: \mathrm{H} 7$ in humans and gnotobiotic piglets. Journal of clinical pathology. 1988;41(10):1099-103.

38. Jacewicz MS, Acheson DW, Binion DG, West GA, Lincicome LL, Fiocchi C, et al. Responses of human intestinal microvascular endothelial cells to Shiga toxins 1 and 2 and pathogenesis of hemorrhagic colitis. Infect Immun. 1999;67(3):1439-44.

39. Donnerstag F, Ding $X$, Pape L, Bültmann E, Lücke $T$, Zajaczek $\mathrm{J}$, et al. Patterns in early diffusion-weighted MRI in children with haemolytic uraemic syndrome and CNS involvement. Eur Radiol. 2012;22(3):506-13.

40. Gallo EG, Gianantonio CA. Extrarenal involvement in diarrhoea-associated haemolytic-uraemic syndrome. Pediatr Nephrol (Berlin, Germany). 1995;9(1):117-9.

41. Tarr PI, Karpman D. Editorial commentary: Escherichia coli O104:H4 and hemolytic uremic syndrome: the analysis begins. Clin Infect Dis. 2012;55(6):760-3.
42. Rother RP, Rollins SA, Mojcik CF, Brodsky RA, Bell L. Discovery and development of the complement inhibitor eculizumab for the treatment of paroxysmal nocturnal hemoglobinuria. Nature Biotechnol. 2007;25(11):1256-64.

43. Clark WF, Sontrop JM, Macnab JJ, Salvadori M, Moist L, Suri R, et al. Long term risk for hypertension, renal impairment, and cardiovascular disease after gastroenteritis from drinking water contaminated with Escherichia coli O157:H7: a prospective cohort study. BMJ (Clinical research ed). 2010;341:c6020 